\title{
Loss of function of the carbon catabolite repressor CreA leads to low but inducer-independent expression from the feruloyl esterase B promoter in Aspergillus niger
}

\author{
Jos Reijngoud • Mark Arentshorst • Claudine Ruijmbeek • Ian Reid • \\ Ebru Demirci Alazi $\cdot$ Peter J. Punt • Adrian Tsang • Arthur F. J. Ram
}

Received: 21 April 2020/Accepted: 8 February 2021/Published online: 18 March 2021

(C) The Author(s) 2021

\begin{abstract}
Objective With the aim to decipher the mechanisms involved in the transcriptional regulation of feruloyl esterase encoded by $f a e B$, a genetic screen was performed to isolate $A$. niger mutants displaying inducer-independent expression from the $f a e B$ promoter.

Result PfaeB-amdS and PfaeB-lux dual reporter strains were constructed and used to isolate transacting mutants in which the expression of both reporters was increased, based on the ability to grow on acetamide plates and higher luciferase activity, respectively. The genetic screen on the non-inducing carbon source D-fructose yielded in total 111 trans-
\end{abstract}

Jos Reijngoud and Mark Arentshorst have contributed equally to this work.

Supplementary Information The online version contains supplementary material available at https://doi.org/10.1007/ s10529-021-03104-2.

J. Reijngoud · M. Arentshorst · C. Ruijmbeek ·

E. D. Alazi · P. J. Punt · A. F. J. Ram ( $\square)$

Molecular Microbiology and Biotechnology, Institute of

Biology Leiden, Leiden University, Sylviusweg 72,

2333 BE Leiden, The Netherlands

e-mail: a.f.j.ram@biology.leidenuniv.nl

Present Address:

J. Reijngoud

Bioscienz, Goeseelsstraat 10, 4817 MV Breda,

The Netherlands acting mutants. The genome of one of the mutants was sequenced and revealed several SNPs, including a point mutation in the $\mathrm{creA}$ gene encoding a transcription factor known to be involved in carbon catabolite repression. Subsequently, all mutants were analyzed for defects in carbon catabolite repression by determining sensitivity towards allyl alcohol. All except four of the 111 mutants were sensitive to allyl alcohol, indicating that the vast majority of the mutants are defective in carbon catabolite repression. The creA gene of 32 allyl alcohol sensitive mutants was sequenced and 27 of them indeed contained a mutation in the creA gene. Targeted deletion of creA in the reporter strain confirmed that the loss of CreA results in constitutive expression from the $f a e B$ promoter.

Conclusion Loss of function of CreA leads to low but inducer-independent expression from the $f a e B$ promoter in A. niger.

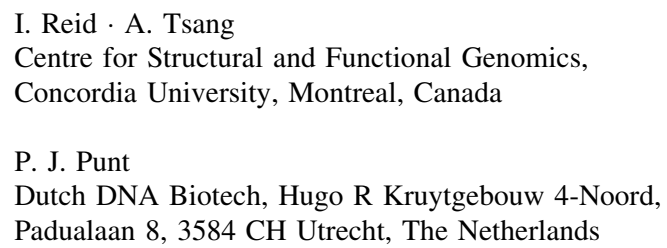


Keywords Aromatic compound · CreA - Ferulic acid · Hydroxycinnamic acid - Luciferase reporter . Plant cell wall

\section{Introduction}

As the most abundant organic carbon source available, plant biomass has a great potential to replace fossil fuels for renewable fuels and chemicals. Lignocellulosic biomass is considered to be the most favorable source for the production of second generation biofuels (Poovaiah et al. 2014). However, lignocellulosic biomass is highly recalcitrant to full and efficient enzymatic degradation by fungal enzyme cocktails. The recalcitrant nature of the lignocellulose is mainly derived from cell wall composition and architecture, and comprises different factors such as cellulose crystallinity, hemicellulose polymerization and substitution pattern, lignin content and composition, and the occlusion of the cell wall by lignin-hydroxycinnamate-hemicellulose cross-linking (McCann and Carpita 2015; Oliveira et al. 2015, 2019). In plant cell walls, ferulic acid (4-hydroxy-3-methoxycinnamic acid) plays a key role in inter- and intra-polymer cross-linking (Terrett and Dupree 2019).

Feruloyl esterases are a subclass of carboxylic esterases with the capacity to release ferulic acid and other hydroxycinnamic acids (such as $p$-coumaric acid) from plant cell wall. Because ferulic acid plays such a crucial role in crosslinking, feruloyl esterases play a key role to remove those cross-links and make the cellulose, hemicellulose and pectin accessible for hydrolysis by cellulases, hemicellulases and pectinases. Indeed, fungal feruloyl esterases have been shown to act synergistically with cellulases and xylanases to facilitate the degradation of complex plant cell wall biomass (Selig et al. 2008; Tabka et al. 2006; Wong et al. 2013).

Aspergillus niger is an important industrial producer of enzymes and an important model organism in relation to transcriptional regulation of plant cell wall degrading enzymes (de Vries et al. 2017; Pel et al. 2007). The genome of $A$. niger contains four genes encoding predicted feruloyl esterases (FaeA-FaeD) of which three (FaeA-FaeC) have been studied in detail (de Vries et al. 2002; Dilokpimol et al. 2017; Levasseur et al. 2004). Comparative analysis of their activities suggested that the different isoenzymes may target different substrates in a complementary manner
(Dilokpimol et al. 2017). The expression of feruloyl esterases in A. niger is tightly regulated. Expression analysis of faeA revealed that the gene is specifically induced on xylose and arabinose (de Vries et al. 2002). Induction of faeA is dependent on the XlnR transcriptional regulator and co-expressed with xylanases and xylosidases (Gruben et al. 2017; van Peij et al. 1998). In addition, faeA was found to be induced on several aromatics including ferulic acid, vanillic acid, vanillyl alcohol, vanillin and veratric acid (de Vries et al. 2002). The $f a e B$ gene was not found to be induced by any carbon source tested, but was found to be strongly induced by aromatic compounds, such as ferulic acid, caffeic acid, and $p$-coumaric acid (de Vries et al. 2002; Dilokpimol et al. 2017). The expression of $f a e C$ was in general very low and induced by cinnamic acid (Dilokpimol et al. 2017). The induction pattern of $f a e A, f a e B$ and $f a e C$ on various aromatic compounds suggests that their induction mechanism is mediated by different transcription factors and inducers.

Apart from being regulated via an induction mechanism, faeB was also shown to be sensitive for carbon catabolite repression in a CreA-dependent way (de Vries et al. 2002). CreA encodes a highly conserved $\mathrm{C} 2 \mathrm{H} 2$ transcriptional repressor that represses the expression of enzymes allowing the preferential utilization of the energetically most favorable carbon source (Dowzer and Kelly 1991; Ries et al. 2016; Ruijter and Visser 1997).

We previously used forward genetic screens based on promoter-amdS reporter constructs, to isolate mutants showing constitutive expression of pectinase (Niu et al. 2017) and arabinase encoding genes (Reijngoud et al. 2019). To obtain insight into the transcriptional regulation of $f a e B$, a similar strategy was used in which PfaeB-amdS and PfaeB-lux double reporter strains were constructed with the aim to identify mutants displaying constitutive, i.e. inducerindependent, expression from the $f a e B$ promoter. Using these reporter strains we show the specific induction of the $f a e B$ promoter by hydroxycinnamic acids. The mutants displaying inducer-independent expression from the $f a e B$ promoter were found to be defective in carbon catabolite repression. 


\section{Materials and methods}

Strains, media and growth conditions

The A. niger strains used in this study are listed in Table 1. Strains were grown on liquid or solidified (containing $1.5 \%$ (w/v) Scharlau agar) minimal medium (MM) or on complete medium (CM) as described (Arentshorst et al. 2012). A. niger transformants were isolated and purified as described (Arentshorst et al. 2012) using a final concentration of $100 \mu \mathrm{g} / \mathrm{mL}$ hygromycin or $20 \mu \mathrm{g} / \mathrm{mL}$ phleomycin. Mycelial growth assays were performed on acetamide plates, i.e. plates containing solidified MM with $10 \mathrm{mM}$ acetamide as sole nitrogen source, $15 \mathrm{mM}$ $\mathrm{CsCl}$ and $50 \mathrm{mM}$ D-fructose, usually supplemented with $2.5 \mathrm{mM}$ of the aromatic compound. Aromatic compounds were weighed, dissolved in sterile water and mixed with an equal volume of $2 \times$ concentrated solidified MM. Radial growth of JR9.9 and JR9.19 was assayed by point inoculation of $5 \mu \mathrm{L}$ filtered spore suspension $\left(1 \times 10^{6}\right.$ spores $\left./ \mathrm{mL}\right)$ in the center of an acetamide plate and incubation of the plates for 7 days at $30{ }^{\circ} \mathrm{C}$. Escherichia coli DH5 $\alpha$ was used for plasmid construction and cultured at $37{ }^{\circ} \mathrm{C}$ in lysogeny broth (LB) medium, with ampicillin $(100 \mu \mathrm{g} / \mathrm{mL})$.

\section{Molecular techniques}

PCR amplifications were performed using Phusion High-Fidelity DNA Polymerase (Thermo Scientific) according to the instructions provided. DNA fragments were purified using the GeneJET Gel Extraction Kit (Thermo Scientific) and ligations were carried out using the CloneJET PCR Cloning Kit and the Rapid
DNA Ligation Kit (Thermo Scientific). DNA sequencing was performed by Macrogen.

\section{Plasmid construction}

The primers used in this study are listed in Suppl. Table 1. Plasmid PfaeB-amdS was constructed as follows: the $A$. niger faeB promoter region (986 bp) was obtained by PCR using primers faeBP1f_NotI and faeABP2r and genomic DNA of N402 (Bos et al. 1988 ) as template. The $2.1 \mathrm{~kb}$ A. nidulans amdS gene was amplified using primers amdSP3f and amdSP4r_NotI and plasmid PagsA-amdS-TamdS (Damveld et al. 2008) as template. The overlap between faeABP2r and amdSP3f was used in a fusion PCR to obtain the $3.1 \mathrm{~kb}$ $P f a e B$-amdS fragment. The fragment was ligated into pJet1.2 (Thermo Scientific) and verified by sequencing to yield plasmid $P f a e B$-amdS.

Plasmid PfaeB-lux 613 was constructed by PCR amplification of the $f a e B$ promoter using primers PfaeB_PmeI_P5f and PfaeB_PmeI_P6r using genomic DNA of $A$. niger strain N402 as a template, and subsequent cloning of the fragment in pJet2.1 to give pJet2.1_PfaeB. The $1 \mathrm{~kb}$ faeB promoter fragment from pJet2.1_PfaeB was obtained after PmeI digestion and cloned into PmeI digested pHT01. pHT01 contains a red firefly luciferase $\left(\lambda_{\max }=613 \mathrm{~nm}\right)$ variant, codon-optimized for $A$. niger, containing a unique PmeI site to insert promoter fragments in front of the $l u x_{613}$ gene (Hein Trip, unpublished vector). After ligation, the PfaeB-lux 613 plasmid was verified by sequencing.

The creA gene was deleted with the split marker method (Arentshorst et al. 2015), using phleomycin as selection marker. creA flanks were amplified using genomic DNA of $A$. niger strain N402 as template and
Table 1 A. niger strains used in this study

\begin{tabular}{lll}
\hline Strain & Genotype & Reference \\
\hline N402 & $c s p A$ & ATCC $\left(64,974{ }^{\text {TM }}\right.$ Bos et al. (1988) \\
AB4.1 & pyrG- derivative of N402 & van Hartingsveldt et al. (1987) \\
MA234.1 & ku70::PgpdA-amdS & Alazi et al. (2016) \\
JR9.9 & PfaeB-amdS in AB4.1 & This study \\
JR9.19 & PfaeB-amdS in AB4.1 & This study \\
JR10.2 & PfaeB-lux in JR9.9 & This study \\
JR11.1 & PfaeB-lux in JR9.19 & This study \\
MA872.1 & AcreA::phleo in JR11.1 & This study \\
\hline
\end{tabular}


primers creA_sm_P1f and creA_sm_P2r (creA 5', $866 \mathrm{bp})$ or primers creA_sm_P3f and creA_sm_P4r (creA 3', 778 bp). Phleomycin fragments were amplified using pAN8.1 (Punt and Van den Hondel 1992) as template and primers phleoP4f and phleoP8r (phleo 5', $1143 \mathrm{bp}$ ) or primers phleoP6f and phleoP5r (phleo 3', $1069 \mathrm{bp}$ ). creA-phleo 5' split marker fragment (1991 bp) was obtained with fusion PCR, using fragments creA 5' and phleo 5' as template and creA_sm_P1f and phleoP8r as primers. creA-phleo 3' split marker fragment (1826 bp) was obtained with fusion PCR, using fragments creA 3' and phleo 3' as template and phleoP6f and creA_sm_P4r as primers. Both split marker fragments were column-purified before transformation to A. niger strain JR11.1.

\section{Fungal transformations}

Plasmid pJet1.2_PfaeB-amdS was introduced to A. niger strain $\mathrm{AB} 4.1$ by co-transformation with pAB4.1 (van Hartingsveldt et al. 1987). Transformants were purified on solidified MM without uridine and subsequently tested for growth on acetamide plates with or without $0.05 \%$ (w/v) ferulic acid. Strain JR9.9 and JR9.19 were selected for their ability to grow on acetamide plates with ferulic acid, indicating that these transformants also had taken up the PfaeB-amdS plasmid. Strains JR9.9 and JR9.19 were subsequently transformed with PfaeB-lux 613 by co-transformation with pAN7.1 (Punt et al. 1987). Purified transformants were analyzed for luciferase expression under noninducing conditions (without ferulic acid or other aromatic compounds) or after addition of $0.05 \%$ ferulic acid. JR10.2 (derived from JR9.9) and JR11.1 (derived from JR9.19) showed low luciferase activity under non-inducing conditions and induction of luciferase activity upon supplementation of the medium with ferulic acid (see also the Results section). The creA gene was deleted in JR11.1 using the split marker method with phleomycin as a selection marker (Punt and Van den Hondel 1992; Arentshorst et al. 2015) and verified by diagnostic PCR using primers listed in Supplementary Table 1.

\section{UV mutagenesis}

UV mutagenesis experiments were performed as described previously (Damveld et al. 2008) using JR10.2 or JR11.1 as starting strains. After determining the killing rate of the UV treatment, spores with 60-70\% survival were plated out on acetamide plates without ferulic acid. On each plate about $5 \times 10^{5}$ spores ( $50 \mu \mathrm{L}$ of $1 \times 10^{7}$ spores/mL suspension) were plated out. In total, around 10 plates for JR10.2 and 60 plates for JR11.1 were prepared and incubated for 7 days at $30{ }^{\circ} \mathrm{C}$. Mutants growing and sporulating on the acetamide plates were purified twice on acetamide plates. Mutants with improved growth on acetamide plates were tested in the luciferase assay to identify trans-acting mutants.

\section{Luciferase assays}

Luciferase (lux) assays were performed as follows: $176 \mu \mathrm{L}$ of MM (containing $1 \%(w / v)$ D-fructose and $0.003 \%$ (w/v) yeast extract), $4 \mu \mathrm{L} 25 \mathrm{mM}$ luciferin (Promega, E1605) and $20 \mu \mathrm{L}$ spore suspension $\left(1 * 10^{6}\right.$ spores $/ \mathrm{mL}$ ) were pipetted together (in triplicate) into a well of a white, clear bottom, 96 wells plate (Greiner Bio-One, ref. 655,095) and incubated for $24 \mathrm{~h}$ at $30{ }^{\circ} \mathrm{C}$ in the Spark $10 \mathrm{M}$ Multimode Microplate reader (Tecan) while measuring luciferase activity and $\mathrm{OD}_{600}$ every $15 \mathrm{~min}$. MM containing $0.1 \%$ (w/v) ferulic acid was prepared by dissolving $0.25 \mathrm{~g}$ ferulic acid in $250 \mathrm{~mL}$ MM, followed by filter sterilization. MM with lower concentrations of ferulic acid was prepared by diluting MM containing $0.1 \%$ ferulic acid with appropriate volumes of MM.

\section{Allyl alcohol sensitivity assay}

Sensitivity towards allyl alcohol was determined by inoculating spores $\left(5 \mu \mathrm{L}\right.$ of $1 * 10^{6}$ spores $\left./ \mathrm{mL}\right)$ on plates containing $\mathrm{MM}$ with D-fructose and increasing concentrations of allyl alcohol $(20 \mathrm{mM}, 40 \mathrm{mM}$ and $60 \mathrm{mM}$ ). Plates were incubated for 7 days at $30{ }^{\circ} \mathrm{C}$ before scoring the ability to grow on plates containing allyl alcohol. 
Genome sequencing and $\operatorname{creA}$ sequencing

Genomic DNA of A. niger strains was isolated as described (Arentshorst et al. 2012). The genomic DNA of strains JR10.2 and UV mutant JR10.2U\#1 was further column-purified (NucleoSpin Plant II, Macherey-Nagel) for whole genome sequencing. The genomes of JR10.2 and JR10.2U\#1 were sequenced at the McGill University Quebec Innovation Centre (QC, Canada) using the Illumina HiSeqX platform to about 50-fold coverage. Mapping of DNA reads to the NRRL3 genome was done using Bowtie2 (Langmead and Salzberg 2012). Sequence differences were detected with Freebayes (Garrison and Marth 2012). The DNA reads described in this study are deposited in the Sequence Read Archive under accession number PRJNA623364.

Sequencing of the creA gene of 32 mutants was performed by PCR amplification of the creA gene including $110 \mathrm{bp}$ promoter and $128 \mathrm{bp}$ terminator regions using the genomic DNA of the mutant as template DNA and primers p2f_creA_dPCR and p3r_creA_dPCR (Suppl. Table 1). Both primers were also used for subsequent sequencing, together with primer creA_rev.

\section{Results}

Construction and analysis of promoter reporter strains to assess $f a e B$ promoter activity in vivo

With the aim to isolate mutants showing constitutive expression from the $f a e B$ promoter, reporter strains were constructed containing the PfaeB-amdS and PfaeB-lux reporters (Table 1). Since both reporters were introduced by co-transformation in which the site of integration or the copy number of the constructs is not known, two independent transformants (JR10.2, derived from JR9.9 and JR11.1, derived from JR9.19) were analyzed to make sure the growth phenotype or reporter activity was not influenced by these factors. In all experiments described below, both reporter strains responded similarly. The specificity of activation or repression of the $f a e B$ promoter by various aromatic compounds or carbon sources was tested in reporter strains JR9.9 and JR9.19 (both containing only the PfaeB-amdS reporter construct). Strains N402 and MA234.1 were included as negative and positive control, respectively. N402 does not contain the A. nidulans amd $S$ gene and therefore cannot grow well on acetamide plates, i.e. solidified MM with acetamide as the sole nitrogen source, while MA234.1 contains the amdS gene expressed from the constitutive gpdA promoter and can therefore grow on acetamide plates. Strain MA234.1 was included also to assess possible toxic effects of the aromatic compounds which could interfere with the induction.

The reporter strains JR9.9 and JR9.19 were not able to grow on acetamide plates without any carbon source or with D-fructose, D-glucose or D-sorbitol as the carbon source. Addition of $0.05 \%$ ferulic acid resulted in growth of the reporter strains, showing the requirement for the presence of a specific inducer for the expression of amdS from the $f a e B$ promoter (Fig. 1a). Carbon sources, such as D-glucose, D-fructose and D-sorbitol, have been previously shown to impose CreA dependent repression on the promoters of genes encoding plant cell wall degrading enzymes including faeB (de Vries et al. 2002). The level of carbon catabolite repression for other promoters of pectinolytic genes such as $\operatorname{pgaX}$ and $\operatorname{pgx} B$ has also been shown to be dependent on the identity of the carbon source and the promoter (Alazi et al. 2018; Niu et al. 2015). Carbon catabolite repression on $\mathrm{faeB}$ promoter imposed by different carbon sources was assessed by adding varying concentrations of D-glucose, D-fructose or D-sorbitol (1 mM-100 mM) in acetamide plates containing $0.05 \%$ ferulic acid. Presence of these carbon sources did not affect the growth of the reporter strains JR9.9 and JR9.19, indicating that the expression of $a m d S$ is at sufficiently high levels to enable growth since the $f a e B$ promoter is highly active in the presence of the inducer (ferulic acid) even when possibly repressing carbon sources are present (Fig. 1b).

Various aromatic compounds were added (final concentration $2.5 \mathrm{mM}$ ) to acetamide plates containing D-fructose and the ability of the reporter strains JR9.9 and JR9.19 to grow was analyzed (Fig. 2a). Fructose was used because it is considered as a non-inducing, non-repressing carbon source. As shown in Fig. 2a, four of the 17 aromatic compounds induced expression from the $f a e B$ promoter which allowed the reporter strain to grow on acetamide plates. These four compounds are ferulic acid, caffeic acid, cinnamic acid and $p$-coumaric acid. Four other compounds $(p$ - 
A

$\mathrm{MM}+10 \mathrm{mM}$ acetamide+

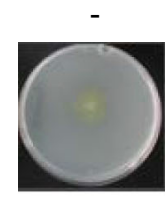

$50 \mathrm{mM}$ D-glucose $50 \mathrm{mM} \mathrm{D-fructose}$

$50 \mathrm{mM}$ D-sorbitol

$0.05 \%$ FA
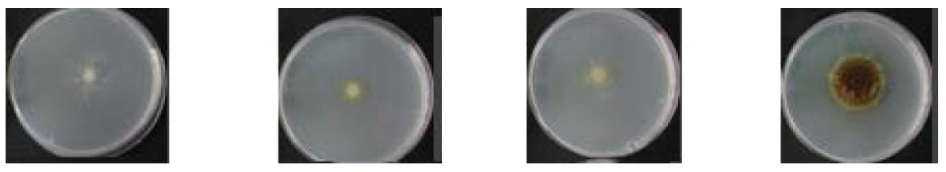

MM+10 mM acetamide+0.05\% FA+

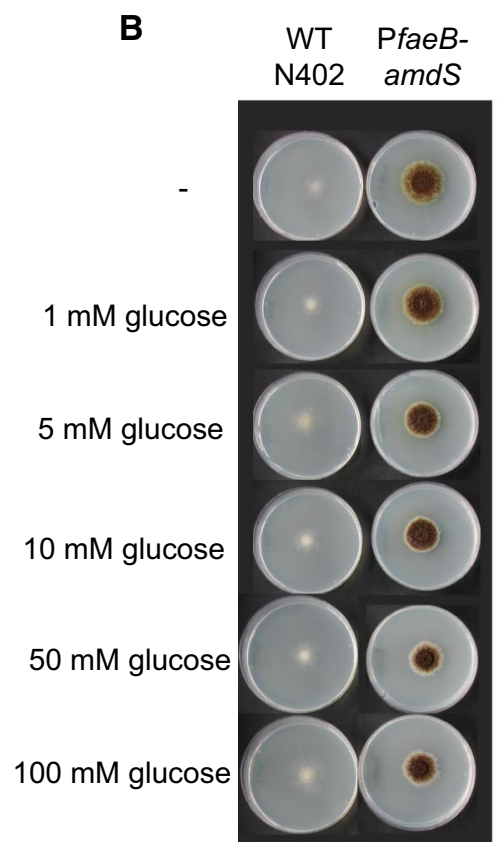

Fig. 1 Growth analysis of A. niger PfaeB-amdS reporter strain (JR9.9). Expression from the faeB promoter is monitored in the PfaeB-amdS reporter strain by analyzing growth on MM with $10 \mathrm{mM}$ acetamide and a $50 \mathrm{mM}$ of different carbon sources or

hydroxybenzoic acid, $p$-anisic acid, benzoic acid and $p$-hydroxybenzaldehyde) moderately induced the expression of $a m d S$ via the $f a e B$ promoter. The addition of $2.5 \mathrm{mM} p$-anisic acid or $p$-vinylguaiacol reduced the growth of MA234.1, indicating that these compounds are toxic at this concentration. These results are largely comparable to the results described by de Vries et al. in which the expression of $f a e B$ was examined by Northern blot analysis after growing cells for two hours after transfer into medium containing various aromatic compounds (de Vries et al. 2002). Similar to our results, caffeic acid, $p$ coumaric acid and ferulic acid gave the strongest induction. In the de Vries study, weak induction of faeB expression by cinnamic acid was observed. In the
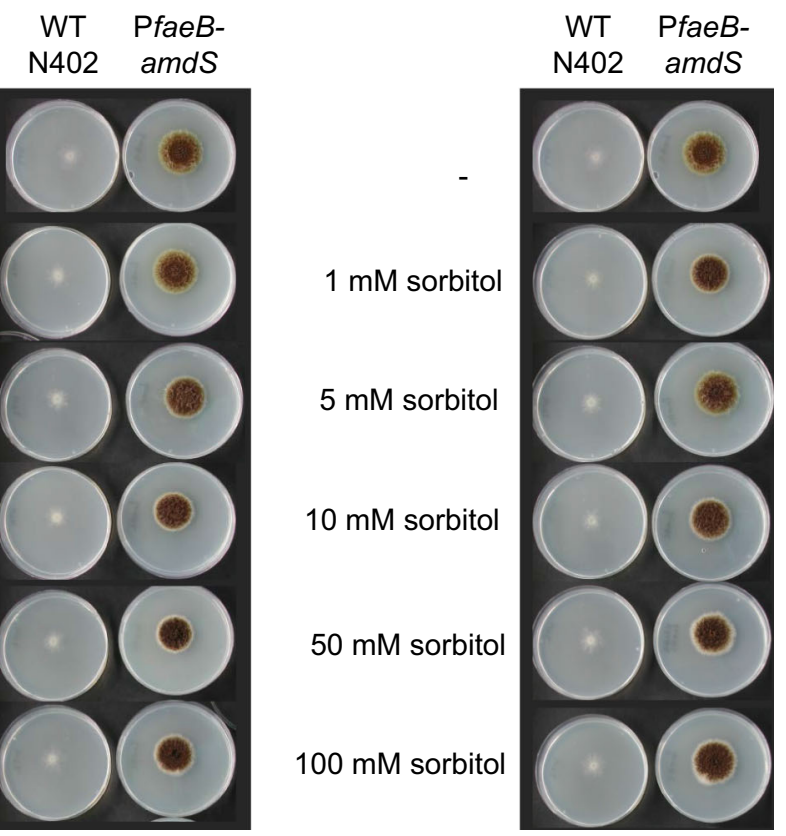

$0.05 \%$ ferulic acid (FA); b $0.05 \%$ FA and increasing concentrations of D-glucose, D-fructose, and D-sorbitol. Strains were grown for 7 days at $30{ }^{\circ} \mathrm{C}$

present study, the robust growth of the reporter strain on acetamide suggests strong induction of $f a e B$ expression by cinnamic acid. $p$-Hydroxybenzoic acid was moderately inducing in both studies, while protocatechuic acid was inducing in the de Vries study, but not in ours. The differences might be explained by the different methods of measuring induction (Northern blot vs. growth readout via pFaeB-controlled AmdS reporter gene expression), the time of exposure to the compounds (induction after two hours vs. induction over days), or with the purity of the compounds. Comparison of the structures of the 17 different compounds (Fig. 2b and Supplementary Fig. 1) shows that the strongly inducing compounds all have a $\mathrm{C} 3$-moiety (prop-2-enoic acid $(-\mathrm{C}=\mathrm{C}-\mathrm{COOH})$ ) 


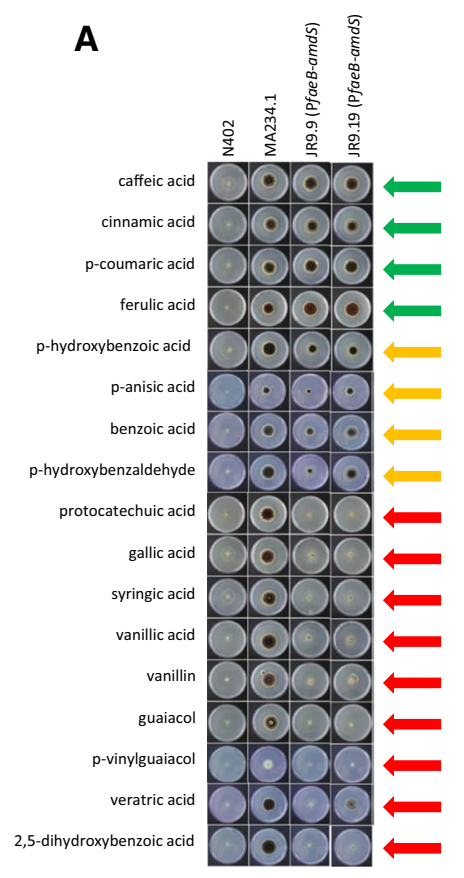

B

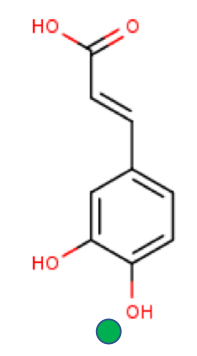

caffeic acid<smiles>O=C(O)c1ccc(O)c(O)c1</smiles>

protocatechuic acid<smiles>O=C(O)/C=C/c1ccccc1</smiles>

cinnamic acid<smiles>O=C(O)c1ccccc1</smiles>

benzoic acid<smiles>O=C(O)/C=C/c1ccc(O)cc1</smiles>

p-coumaric acid<smiles>O=C(O)c1ccc(O)cc1</smiles>

$\bigcirc$ p-hydroxy-
benzoic acid<smiles>COc1cc(/C=C/C(=O)O)ccc1O</smiles>

ferulic acid

Fig. 2 Expression from the $f a e B$ promoter is induced by various aromatic compounds. a Spores of reporter strains JR9.9 and JR9.19 and of control strains N402 and MA234.1 were inoculated on $\mathrm{MM}$ containing $1 \%$ D-fructose, $10 \mathrm{mM}$ acetamide and $2.5 \mathrm{mM}$ of one of the different aromatic compounds. Pictures were taken after incubation for 7 days at

attached to the aromatic ring structure, suggesting that this C3-moiety is essential for activation of the faeB promoter. This specificity is also apparent from the observation that vanillic acid, $p$-hydroxy-benzoic acid, benzoic acid and protocatechuic acid, which have an identical aromatic ring structure as ferulic acid, $p$-coumaric acid, cinnamic acid, and caffeic acid respectively; but a $\mathrm{C} 1$ moiety $(\mathrm{COOH})$ attached to the aromatic ring (Fig. 2b) do not induce high expression. The four moderately inducing compounds ( $p$-hydroxybenzoic acid, $p$-anisic acid, benzoic acid and $p$ hydroxybenzaldehyde) lack the C3-moiety but share with the strongly inducing compounds the property that allylic side chains are absent (benzoic acid) or only found in the R4/para position on the aromatic ring. Additional allylic chains e.g. at the $\mathrm{R} 3$ position in protocatechuic acid decrease induction (Fig. 2b and Supplementary Fig. 1).

The ability of ferulic acid to induce gene expression from the $f a e B$ promoter was also analyzed in $P f a e B$ lux reporter strains JR10.2 and JR11.1 by measuring luciferase activity during the first $24 \mathrm{~h}$ of growth. For

$30^{\circ} \mathrm{C}$. The green, orange or red arrows next to the plates indicate high, moderate or low expression from the faeB promoter, respectively. b Chemical structures of nine of the aromatic compounds tested. The green, yellow or red dots, represent relative high, moderate or low induction of expression from the faeB promoter

this analysis, spores were inoculated in MM containing D-fructose with or without ferulic acid as inducing compound. As shown in Fig. 3 and Supplementary Fig. 2, the addition of ferulic acid induces luciferase activity in both reporter strains (JR10.2 and JR11.1) in a concentration-dependent way. The highest induction after $24 \mathrm{~h}$ was obtained when spores were germinated in the presence of $0.05 \%(2.6 \mathrm{mM})$ ferulic acid (approximately 12,000 cps). Higher concentrations resulted in higher lux levels but had an inhibitory effect on the growth, resulting in lower lux levels after $24 \mathrm{~h}$. Under non-inducing conditions, an approximately 20 times lower luminescence signal (approximately $500 \mathrm{cps}$ ) was detected after $24 \mathrm{~h}$. This reflects the basal expression of luciferase from the $f a e B$ promoter under non-inducing conditions. 


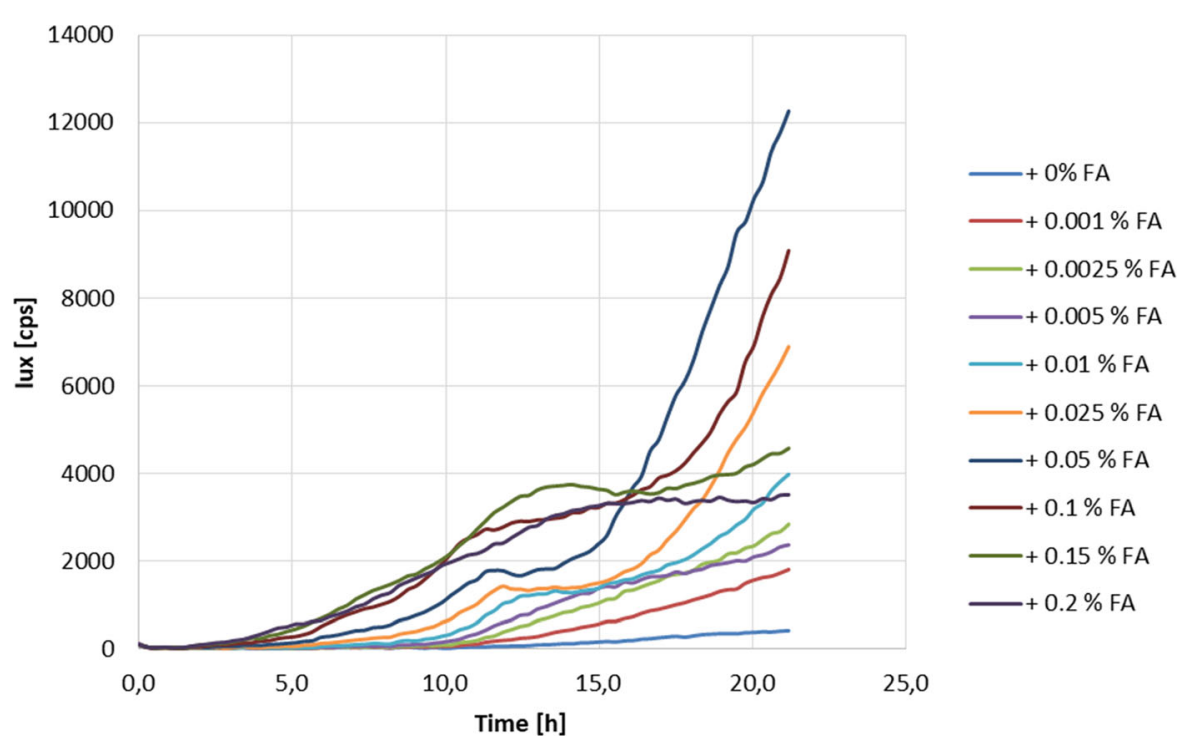

Fig. 3 Expression of PfaeB-lux is induced by ferulic acid in a concentration dependent manner. Expression of the lux reporter gene in strain JR10.2 was measured in a lux assay, using MM with D-fructose as carbon source with the addition of different

lsolation of trans-acting mutants displaying inducer independent expression from the faeB promoter

To obtain mutants with constitutive expression from the $f a e B$ promoter, spores of reporter strains JR10.2 and JR11.1 were UV-mutagenized (60-70\% survival rate) and plated out on acetamide plates containing D-fructose. Mutants that were able to grow and sporulate well on these plates were purified twice on acetamide plates containing D-fructose (Fig. 4a and b). After the plate screening, 13 strains in the JR10.2 background and 114 strains in the JR11.1 background were tested for luciferase activity to determine whether the mutations had a positive effect on both reporters expressed from the $f a e B$ promoter and are therefore trans-acting. All 13 mutants in the JR10.2 background and 98 mutants in the JR11.1 background showed $>2.5$-fold higher luciferase activity compared to their corresponding parental strains under non-inducing conditions. The 2.5 -fold was set as an arbitrary threshold level to consider these mutants as trans-acting mutants (Fig. $4 \mathrm{c}$ and Supplementary Table 2). In the absence of ferulic acid as inducer, a low luminescence signal (approximately $400 \mathrm{cps}$ ) was detected in reporter strains JR10.2 and JR11.1 after $20 \mathrm{~h}$ of growth (Fig. 4c and Supplementary Fig. 2). ln concentrations $(0 \%-0.2 \%)$ of ferulic acid (FA). Growth and luciferase activity were measured every $15 \mathrm{~min}$ for $24 \mathrm{~h}$ at $30{ }^{\circ} \mathrm{C}$

the trans-acting mutants, under non-inducing conditions, the luminescence values varied among the transformants but were in general between four and 10 times higher than their corresponding parental strains (approximately $2500 \mathrm{cps}$ in JR11.1 U\#73) (Fig. 4c and Supplementary Table 2). When the inducer was present, a luminescence value of approximately $10,000 \mathrm{cps}$ was reached in reporter strains JR10.2 and JR11.1 after $20 \mathrm{~h}$, showing a clear induction of about 20-fold compared to the luminescence under non-inducing conditions (Fig. 3 and Supplementary Fig. 2). In the trans-acting mutants, the luminescence signal was three to five times higher in the presence of inducer (approximately 35,000 cps in JR11.1 U\#73) compared to their corresponding parental strains (Fig. 4d and Supplementary Table 2). The results show that the expression from the $\mathrm{faeB}$ promoter was three to 10 times higher in the trans-acting mutants in the presence of $\mathrm{D}$-fructose regardless of the presence of the inducer.

\section{Genome sequencing of JR10.2U\#1}

To identify the mutation(s) responsible for the higher expression of the reporter genes via the $f a e B$ promoter 
A

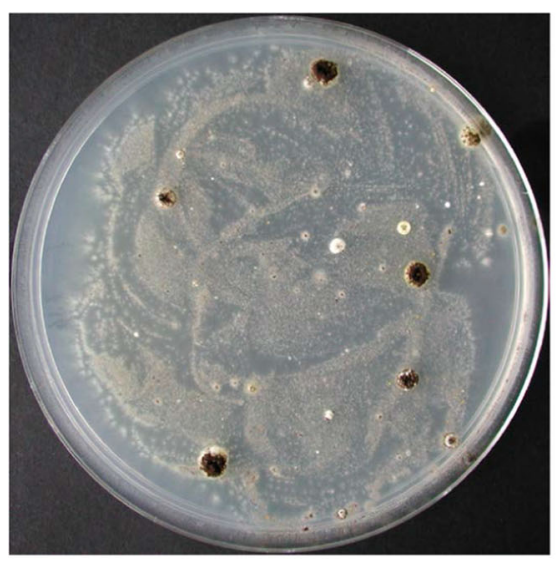

C

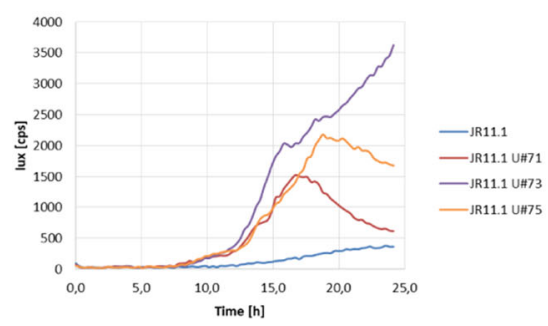

Fig. 4 UV mutagenesis of JR11.1 results in mutants that show ferulic acid independent expression of amdS and lux. Spores of reporter strain JR11.1 were exposed to a series of UV light doses, and the survival rate after each dose was determined. a Spores with a survival rate of $\pm 60 \%$ were plated out on selective medium ( $1 \%$ D-fructose $+10 \mathrm{mM}$ acetamide).

in JR10.2U\#1, the genomes of this mutant and its parental strain JR10.2 were sequenced and compared to each other. We identified in total 66 SNPs (Suppl. Table 3) of which 14 were located in coding regions of annotated genes (Table 2). Of those 14 SNPs, the mutation in the gene encoding the carbon catabolite repressor protein $\mathrm{CreA}$ was considered most relevant to explore further. The $\mathrm{G}$ to A point mutation results in $\mathrm{R}$ (arginine) to $\mathrm{C}$ (cysteine) amino acid change at position 117 of the CreA protein. The R117 is located in the second $\mathrm{C} 2 \mathrm{H} 2$ motif in the CreA protein and is therefore likely to affect the DNA binding of CreA, possibly leading to an inactive CreA protein.

To determine whether JR10.2U\#1 and the other isolated mutants were mutated in the creA gene, first all mutants were tested for their sensitivity towards allyl alcohol. CreA represses alcohol dehydrogenase which converts allyl alcohol into acrolein, a toxic compound, and therefore creA loss-of-function
B

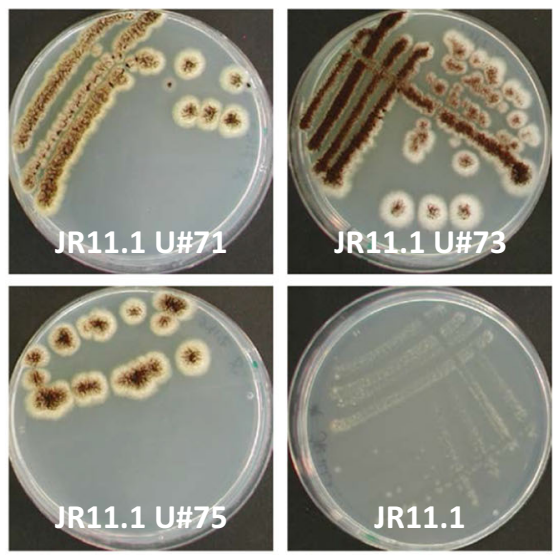

D

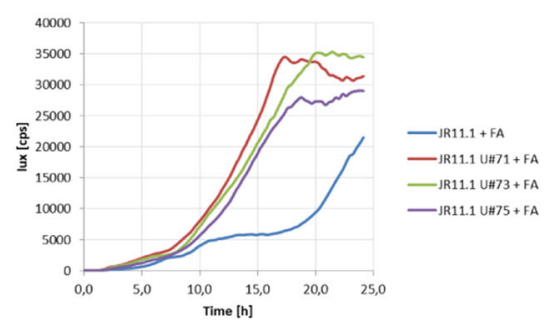

b Mutants that were able to grow were purified on selective medium. $\mathbf{c}$ and $\mathbf{d}$ Expression of the second reporter gene $l u x$ was measured in a lux assay, using D-fructose as carbon-source without (c) or with the addition of ferulic acid (FA) (D). Growth and luciferase activity were measured every $15 \mathrm{~min}$ for $24 \mathrm{~h}$ at $30{ }^{\circ} \mathrm{C}$

mutants are more sensitive to allyl alcohol (Bailey and Arst 1975). All 13 mutants in the JR10.2 background and all 98 mutants in the JR11.1 background were more sensitive to allyl alcohol. From these results we concluded that our screen preferentially selects creA loss-of-function mutants resulting in sufficient expression of the amdS gene from the $f a e B$ promoter to allow growth on acetamide plates. To verify whether mutations in creA were responsible for the constitutive activation of the $f a e B$ promoter, the cre $A$ gene was sequenced in the 12 additional mutants in the JR10.2 background, and in 20 randomly picked mutants in the JR11.1 background. Among the 12 JR10.2-derived mutants, 10 mutants contain a mutation in the creA gene. Two mutants (JR10.2 U\#92 and JR10.2 U\#98) did not contain a mutation in the creA gene. In the JR11.1 background, three of the 20 mutants (JR11.1 U\#3, JR11.1 U\#19 and JR11.1 U\#79) do not contain a mutation in the creA coding region, 
Table 2 Single nucleotide polymorphisms identified in ORFs in JR10.2 U\#1

\begin{tabular}{|c|c|c|c|c|c|c|c|}
\hline Gene & Chromosome & Position & Description & JR10.2 & JR10.2U\#1 & JR10.2 & JR10.2U\#1 \\
\hline & & & & \multirow{2}{*}{\multicolumn{2}{|c|}{$\begin{array}{l}\text { Change at } \\
\text { DNA-level }\end{array}$}} & \multirow{2}{*}{\multicolumn{2}{|c|}{$\begin{array}{l}\text { Change at } \\
\text { Protein level }\end{array}$}} \\
\hline & & & & & & & \\
\hline NRRL3_01879 & chr_2_2 & 829,765 & Hypothetical protein & $\mathrm{A} \rightarrow$ & $\mathrm{G}$ & $\mathrm{R} \rightarrow$ & G \\
\hline NRRL3_02036 & chr_2_2 & $1,345,440$ & Hypothetical protein & $\mathrm{G} \rightarrow$ & $\mathrm{T}$ & $\mathrm{G} \rightarrow$ & W \\
\hline NRRL3_02212 & chr_2_2 & $1,846,987$ & $\begin{array}{l}\text { Glycerol-3-phosphate dehydrogenase } \\
{[\mathrm{NAD}(+)]}\end{array}$ & $\mathrm{G} \rightarrow$ & $\mathrm{T}$ & $\mathrm{F} \rightarrow$ & $\mathrm{L}$ \\
\hline NRRL3_03761 & chr_3_2 & 660,719 & MFS-type transporter & $\mathrm{A} \rightarrow$ & G & $\mathrm{I} \rightarrow$ & $\mathrm{V}$ \\
\hline NRRL3_03766 & chr_3_2 & 674,141 & Short-chain dehydrogenase/reductase & $\mathrm{A} \rightarrow$ & G & $\mathrm{L} \rightarrow$ & $\mathrm{P}$ \\
\hline NRRL3_04117 & chr_3_2 & $1,678,195$ & $\begin{array}{l}\text { Ankyrin repeat domain-containing } \\
\text { protein }\end{array}$ & $\mathrm{T} \rightarrow$ & A & $\mathrm{Y} \rightarrow$ & *STOP \\
\hline NRRL3_05946 & chr_4_2 & $2,766,869$ & Carbon catabolite repressor CreA & $\mathrm{G} \rightarrow$ & A & $\mathrm{R} \rightarrow$ & $\mathrm{C}$ \\
\hline NRRL3_06062 & chr_4_2 & $3,130,181$ & K Homology domain-containing protein & $\mathrm{G} \rightarrow$ & A & $\mathrm{T} \rightarrow$ & I \\
\hline NRRL3_06809 & chr_5_2 & 724,637 & $\begin{array}{l}\text { Alcohol dehydrogenase domain- } \\
\text { containing protein }\end{array}$ & $\mathrm{T} \rightarrow$ & $\mathrm{C}$ & $\mathrm{F} \rightarrow$ & $\mathrm{L}$ \\
\hline NRRL3_07149 & chr_5_2 & $1,707,985$ & Hypothetical protein & $\mathrm{A} \rightarrow$ & G & $\mathrm{R} \rightarrow$ & G \\
\hline NRRL3_08507 & chr_6_1 & $3,452,789$ & Uncharacterized protein & $\mathrm{C} \rightarrow$ & A & $\mathrm{K} \rightarrow$ & $\mathrm{N}$ \\
\hline NRRL3_10110 & chr_7_2 & $2,632,138$ & Carboxylesterase family protein & $\mathrm{CT} \rightarrow$ & $\mathrm{C}$ & $\mathrm{AF} \rightarrow$ & $\begin{array}{r}\text { Frame } \\
\text { shift }\end{array}$ \\
\hline NRRL3_11650 & chr_8_2 & $2,869,882$ & Sas10/Utp3/C1D family protein & $\mathrm{C} \rightarrow$ & $\mathrm{T}$ & $\mathrm{E} \rightarrow$ & $\mathrm{K}$ \\
\hline NRRL3_11661 & chr_8_2 & $2,900,726$ & Cation efflux transporter family protein & GT $\rightarrow$ & AA & $\mathrm{KF} \rightarrow$ & KI \\
\hline
\end{tabular}

whereas the remaining 17 mutants have a mutation in the creA gene. In Fig. 5a and b, and Suppl. Table 2, the location of the mutations and the frequency of finding a certain creA allele in the mutants is shown. From the 27 mutants with mutations in $c r e A, 22$ mutants were found to have a mutation in either the first $\mathrm{C} 2 \mathrm{H} 2$ motif (7 mutants) or the second $\mathrm{C} 2 \mathrm{H} 2$ motif (15 mutants). Moreover, several alleles were found multiple times; e.g. the L113STOP or R117C mutations were found six and four times, respectively, in independently isolated mutants. The C78S mutation was found twice and three different amino acid changes were found at the $\mathrm{C} 106$ position (C106S, C106Y, and C106P) suggesting that there is a preference for certain mutations at certain positions in the $c r e A$ gene. Five mutants contain small deletions or insertions in the creA gene leading to frame shifts (Fig. 5a). From the analysis, it became clear that our screen strongly selects for mutants with mutations in the DNA binding domain of CreA ( 25 out of 27 mutants). It is also clear from the analysis of the mutants that the two different genetic backgrounds used (JR10.2 and JR11.1) did not affect the outcome of the genetic screen. In only two mutants (JR11.1 U\#6 and JR10.2 U\#80) the DNA binding motif is not mutated, but frame shift mutations occur after the DNA binding domains resulting in a non-functional protein. The growth phenotype on acetamide and allyl alcohol and the expression of luciferase under non-inducing and inducing conditions of these mutants was not different from the other mutants. The strong bias to isolate mutant in the DNAbinding motif strongly suggests that lack of binding of creA to the promoter is important to reach the state of inducer-independent expression from the $f a e B$ promoter. The $1 \mathrm{~kb}$ promoter of $f a e B$ contains 14 putative CreA binding sites (5'-SYGGRG-3') and the lack of CreA binding to the promoter may have an important influence on the accessibility and binding of the transcription activation complex to the promoter.

Targeted deletion of $c r e A$ in the reporter strain results in ferulic acid-independent activation of the $f a e B$ promoter

To confirm that loss of function of creA is responsible for the constitutive activation of the $f a e B$ promoter, the creA gene was deleted in the JR11.1 reporter strain 


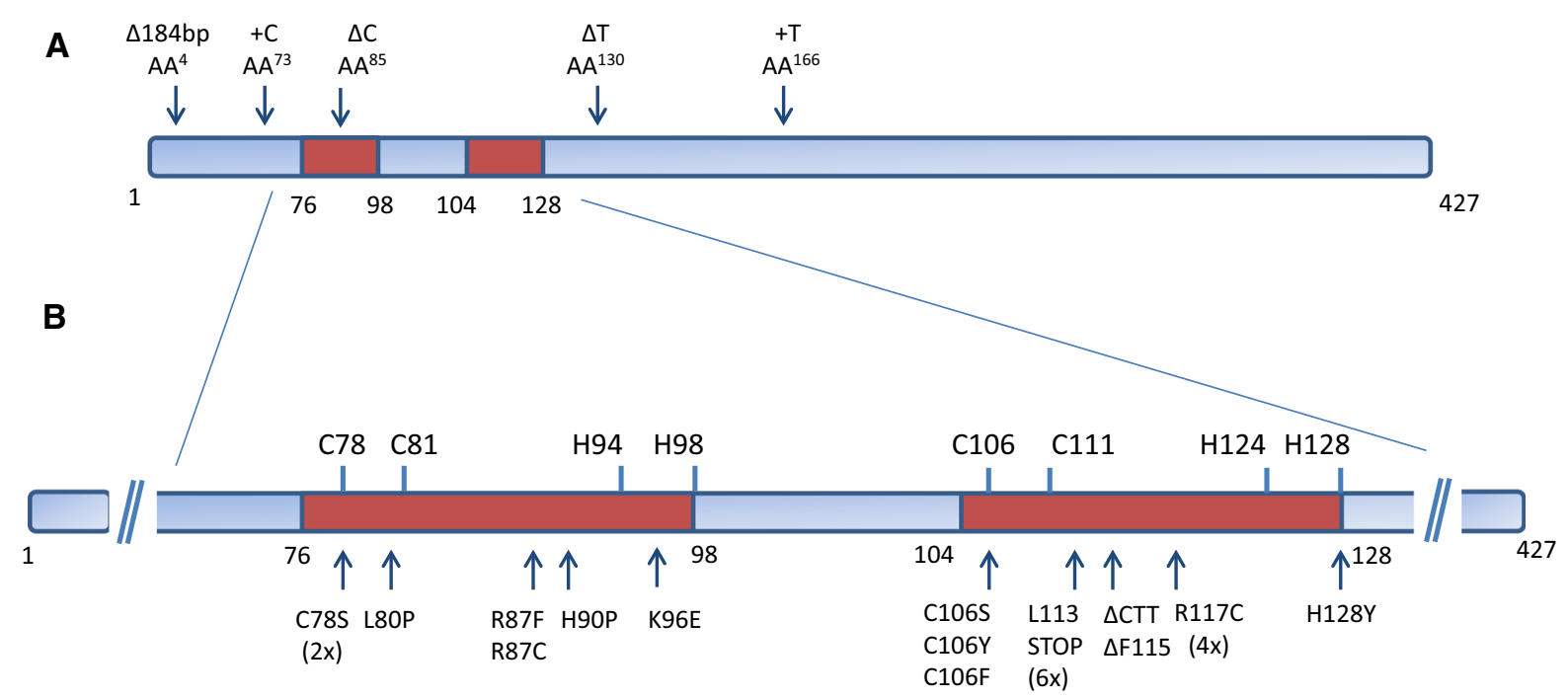

Fig. 5 Mutations in CreA mainly occur in the $\mathrm{C} 2 \mathrm{H} 2$ Zinc Finger DNA binding domains shown in brownish red. a Position in five mutants in which a deletions or insertion occurred. b Position and amino acid change in 22 mutants

using split marker fragments (Arentshorst et al. 2015). Proper replacement of the creA gene by the phleomycin resistance marker was verified via diagnostic PCR (Supplementary Fig. 3). Subsequent growth analysis showed that deletion of creA in the JR11.1 reporter strain allowed the strain to grow on acetamide plates containing D-fructose without inducer (Fig. 6a and b). Deletion of $c r e A$ in the dual reporter strain resulted in a 8 -fold induction of luminescence under non-inducing conditions (Fig. 6c), confirming that inactivation of CreA leads to inducer-independent expression from the $f a e B$ promoter. We further addressed the question whether the expression from the $f a e B$ promoter was also affected by the absence of CreA when the inducer is present. As shown in Fig. 6d, luminescence was about four-times higher in the $\triangle c r e A$ reporter strain compared to the reporter strain with intact creA, similar as observed for the mutants selected in our screen. This confirms that CreA represses the expression from the $f a e B$ promoter in the presence of both D-fructose and ferulic acid.

\section{Conclusions}

Lignocellulosic biomass is considered to be the most favorable source for the production of second generation biofuels and other bio-based building blocks (Fatma et al. 2018; Poovaiah et al. 2014). Optimal enzyme cocktails are necessary for the efficient degradation of the lignocellulose into monosaccharides and aromatics. Ferulic acid is an important cross-linker in plant cell walls causing inefficient hydrolysis. To discover ways to enrich enzyme cocktails for enhanced presence of feruloyl esterases, this study was conducted to understand transcriptional regulation of feruloyl esterase $\mathrm{B}$ in $A$. niger. By identifying (transcription) factor(s) that control expression of $f a e B$, approaches to modulate these transcription factors could lead to higher production of feruloyl esterases in cocktails (Alazi and Ram 2018). To search for transcription factors involved in $f a e B$ regulation a forward genetic screen was performed to obtain mutants with a constitutive expression from the $f a e B$ promoter. Many of the mutants contained a loss of function mutation in CreA, indicating that CreA plays an essential role in the repression of $f a e B$ on $D$-fructose. The detailed analysis of the mutants showed that most of the creA mutants carried mutations in the DNA binding motif, making them loss of function mutations. Although it has been reported that $f a e B$ expression is higher in the cre $A$ mutant (de Vries et al. 2002), this is the first study that shows that the deletion of creA leads to low but constitutive expression from the $f a e B$ promoter on 
Fig. 6 Deletion of creA in JR11.1 results in ferulic acid independent expression from the $f a e B$ promoter. $\mathbf{a}$ and $\mathbf{b}$ Strains JR11.1 and JR11.1 $\triangle$ creA were grown on MM containing $1 \%$ D-fructose and $10 \mathrm{mM}$ acetamide at $30{ }^{\circ} \mathrm{C}$ for five days. $\mathbf{c}$ and $\mathbf{d}$ Lux assay was performed on strains JR11.1 and JR11.1 $\triangle c r e A$, using D-fructose as carbon source without (c) or with the addition of ferulic acid (FA) (d). Growth and luciferase activity were measured every $15 \mathrm{~min}$ for $24 \mathrm{~h}$ at $30{ }^{\circ} \mathrm{C}$
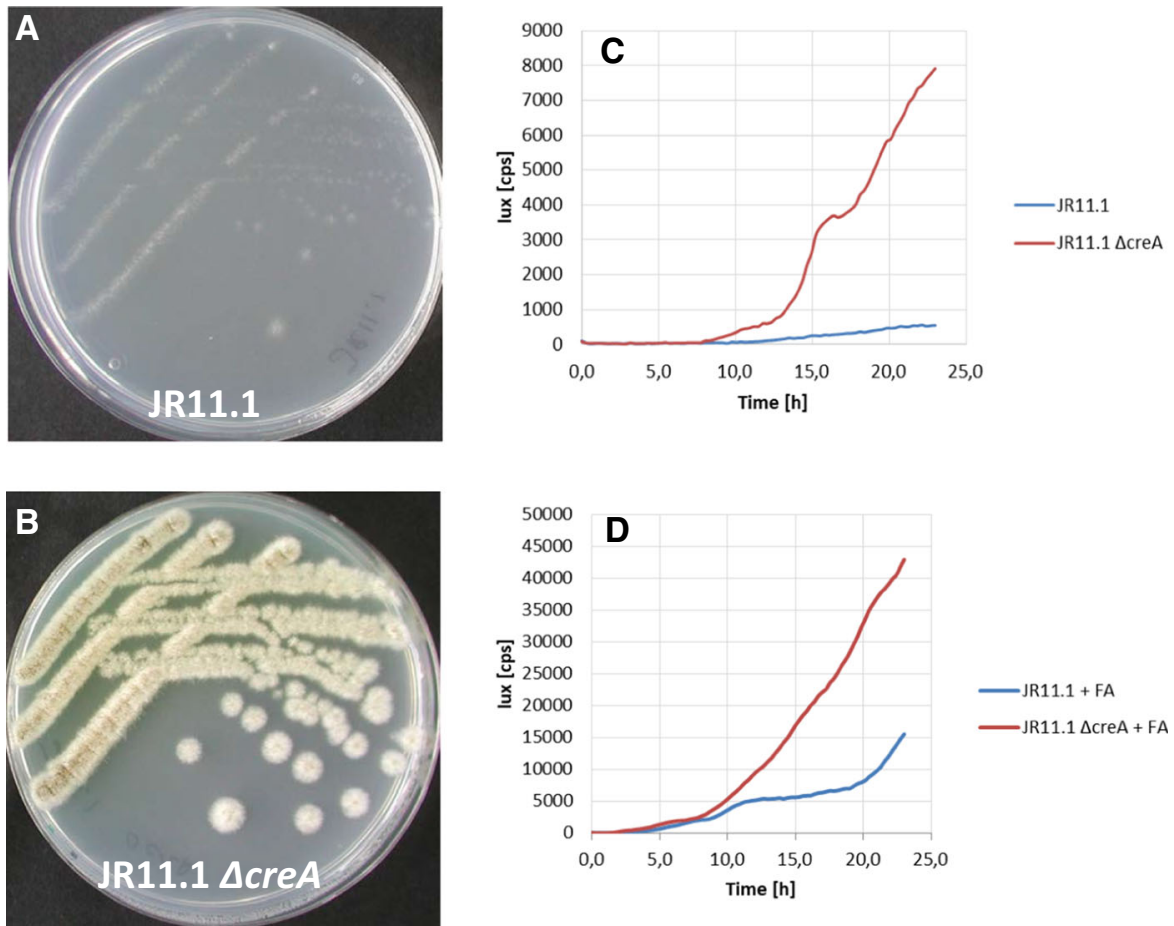

D-fructose without an aromatic inducer. While a CreA loss-of-function leads to a low expression from the $f a e B$ promoter on $\mathrm{D}$-fructose, addition of a strong inducer, such as ferulic acid, results in a much higher expression as has also been observed by de Vries et al. 2002. To find additional factors involved in the carbon catabolite related transcriptional control of $f a e B$, the mutants that do show constitutive expression from the $f a e B$ promoter but have no mutation in $c r e A$, are currently being investigated further.

Acknowledgements We thank Dr. Hein Trip for sharing the pHT1 plasmid prior to publication. We also thank Juliette Tridon, Nakisa Echobardo, Metin Yarim, Lucas Heijnen and Pascal Nuijten for their help with the isolation of mutants.

Supporting information Supplementary Figure 1-Chemical structure of remaining compounds listed in Figure 1a.

Supplementary Figure 2-Expression of PfaeB-lux in JR11.1.

Supplementary Figure 3-Diagnostic PCR for confirmation of creA deletion in JR11.1.

Supplementary Table 1-Primers used in this study.

Supplementary Table 2-Characteristics of PfaeB mutants.

Supplementary Table 3-SNPs in JR10.2U\#1.

Author contributions JR, MA, CR, IR, and EDA performed the research; all authors were involved in analysis of the data.
AR, PP and AT conceived the study. MA and AR wrote the major part of the manuscript with the help of all other authors.

Funding No funding was received for conducting this study.

Data availability The DNA reads described in this study are deposited in the Sequence Read Archive under accession number PRJNA623364. Other materials are available under request.

\section{Compliance with ethical standards}

Conflict of interest All authors declare that they have no conflict of interest.

Ethical approval This article does not contain any studies with human participants or animals performed by any of the authors.

Open Access This article is licensed under a Creative Commons Attribution 4.0 International License, which permits use, sharing, adaptation, distribution and reproduction in any medium or format, as long as you give appropriate credit to the original author(s) and the source, provide a link to the Creative Commons licence, and indicate if changes were made. The images or other third party material in this article are included in the article's Creative Commons licence, unless indicated otherwise in a credit line to the material. If material is not included in the article's Creative Commons licence and your intended use is not permitted by statutory regulation or exceeds the permitted use, you will need to obtain permission directly 
from the copyright holder. To view a copy of this licence, visit http://creativecommons.org/licenses/by/4.0/.

\section{References}

Alazi E, Knetsch T, Di Falco M, Reid ID, Arentshorst M, Visser J, Tsang A, Ram AF (2018) Inducer-independent production of pectinases in Aspergillus niger by overexpression of the D-galacturonic acid-responsive transcription factor GaaR. Appl Microbiol Biotechnol 102:2723-2736. https:// doi.org/10.1007/s00253-018-8753-7

Alazi E, Niu J, Kowalczyk JE, Peng M, Aguilar Pontes MV, van Kan JA, Visser J, de Vries RP, Ram AF (2016) The transcriptional activator GaaR of Aspergillus niger is required for release and utilization of D-galacturonic acid from pectin. FEBS Lett 590(12):1804-1815. https://doi.org/10. 1016/j.ophtha.2013.03.046

Alazi E, Ram AF (2018) Modulating transcriptional regulation of plant biomass degrading enzyme networks for rational design of industrial fungal strains. Front Bioeng Biotechnol 6:133. https://doi.org/10.1016/j.ophtha.2013.03.046

Arentshorst M, Niu J, Ram AF (2015) Efficient generation of Aspergillus niger knock out strains by combining NHEJ mutants and a split marker approach. In: van den Berg MA, Maruthachalam K (eds) Genetic transformation systems in fungi. Springer, Berlin, pp 263-272

Arentshorst M, Ram AF, Meyer V (2012) Using non-homologous end-joining-deficient strains for functional gene analyses in filamentous fungi. Plant Fungal Pathog 835:133-150. https://doi.org/10.1007/978-1-61779-5015_9

Bailey C, Arst HN Jr (1975) Carbon catabolite repression in Aspergillus nidulans. Eur J Biochem 51(2):573-577

Bos CJ, Debets AJ, Swart K, Huybers A, Kobus G, Slakhorst SM (1988) Genetic analysis and the construction of master strains for assignment of genes to six linkage groups in Aspergillus niger. Curr Genet 14(5):437-443

Damveld RA, Franken A, Arentshorst M, Punt PJ, Klis FM, van den Hondel CA, Ram AF (2008) A novel screening method for cell wall mutants in Aspergillus niger identifies UDPgalactopyranose mutase as an important protein in fungal cell wall biosynthesis. Genetics 178(2):873-881. https:// doi.org/10.1534/genetics.107.073148

de Vries RP, Riley R, Wiebenga A, Aguilar-Osorio G, Amillis S, Uchima CA, Anderluh G, Asadollahi M, Askin M, Barry K, Battaglia E, Bayram Ö, Benocci T, Braus-Stromeyer SA, Caldana C, Cánovas D, Cerqueira GC, Chen F, Chen W, Choi C, Clum A, Dos Santos RA, Damásio AR, Diallinas G, Emri T, Fekete E, Flipphi M, Freyberg S, Gallo A, Gournas C, Habgood R, Hainaut M, Harispe ML, Henrissat B, Hildén KS, Hope R, Hossain A, Karabika E, Karaffa L, Karányi Z, Kraševec N, Kuo A, Kusch H, LaButti K, Lagendijk EL, Lapidus A, Levasseur A, Lindquist E, Lipzen A, Logrieco AF, MacCabe A, Mäkelä MR, Malavazi I, Melin P, Meyer V, Mielnichuk N, Miskei M, Molnár ÁP, Mulé G, Ngan CY, Orejas M, Orosz E, Ouedraogo JP, Overkamp KM, Park HS, Perrone G, Piumi F, Punt PJ,
Ram AF, Ramón A, Rauscher S, Record E, Riaño-Pachón DM, Robert V, Röhrig J, Ruller R, Salamov A, Salih NS, Samson RA, Sándor E, Sanguinetti M, Schütze T, Sepčić K, Shelest E, Sherlock G, Sophianopoulou V, Squina FM, Sun H, Susca A, Todd RB, Tsang A, Unkles SE, van de Wiele N, van Rossen-Uffink D, Oliveira JV, Vesth TC, Visser J, Yu JH, Zhou M, Andersen MR, Archer DB, Baker SE, Benoit I, Brakhage AA, Braus GH, Fischer R, Frisvad JC, Goldman GH, Houbraken J, Oakley B, Pócsi I, Scazzocchio C, Seiboth B, vanKuyk PA, Wortman J, Dyer PS, Grigoriev IV (2017) Comparative genomics reveals high biological diversity and specific adaptations in the industrially and medically important fungal genus Aspergillus. Genome Biol 18:28. https://doi.org/10.1186/s13059-0171151-0

de Vries RP, vanKuyk PA, Kester HC, Visser J (2002) The Aspergillus niger faeB gene encodes a second feruloyl esterase involved in pectin and xylan degradation and is specifically induced in the presence of aromatic compounds. Biochem J 363(Pt 2):377-386

Dilokpimol A, Mäkelä MR, Mansouri S, Belova O, Waterstraat M, Bunzel M, de Vries RP, Hildén KS (2017) Expanding the feruloyl esterase gene family of Aspergillus niger by characterization of a feruloyl esterase. FaeCN Biotechnol 37(Pt B):200-209. https://doi.org/10.1016/j.nbt.2017.02. 007

Dowzer CE, Kelly JM (1991) Analysis of the creA gene, a regulator of carbon catabolite repression in Aspergillus nidulans. Mol Cell Biol 11(11):5701-5709

Fatma S, Hameed A, Noman M, Ahmed T, Shahid M, Tariq M, Sohail I, Tabassum R (2018) Lignocellulosic biomass: a sustainable bioenergy source for the future. Protein Pept Lett 25(2):148-163. https://doi.org/10.1016/j.ophtha.2013. 03.046

Garrison E, Marth G (2012) Haplotype-based variant detection from short-read sequencing. arXiv. 1207

Gruben BS, Mäkelä MR, Kowalczyk JE, Zhou M, Benoit-Gelber I, De Vries RP (2017) Expression-based clustering of CAZyme-encoding genes of Aspergillus niger. BMC Genom 18(1):900. https://doi.org/10.1186/s12864-0174164-x

Langmead B, Salzberg SL (2012) Fast gapped-read alignment with Bowtie 2. Nat Methods 9(4):357-359. https://doi.org/ 10.1016/j.ophtha.2013.03.046

Levasseur A, Pagès S, Fierobe HP, Navarro D, Punt P, Belaïch JP, Asther M, Record E (2004) Design and production in Aspergillus niger of a chimeric protein associating a fungal feruloyl esterase and a clostridial dockerin domain. Appl Environ Microbiol 70(12):6984-6991

McCann MC, Carpita NC (2015) Biomass recalcitrance: a multi-scale, multi-factor, and conversion-specific property. J Exp Bot 66(14):4109-4118. https://doi.org/10.1016/j. ophtha.2013.03.046

Niu J, Alazi E, Reid ID, Arentshorst M, Punt PJ, Visser J, Tsang A, Ram AF (2017) An evolutionarily conserved transcriptional activator-repressor module controls expression of genes for D-galacturonic acid utilization in Aspergillus niger. Genetics 205(1):169-183. https://doi.org/10.1016/j. ophtha.2013.03.046

Niu J, Homan TG, Arentshorst M, de Vries RP, Visser J, Ram AF (2015) The interaction of induction and repression 
mechanisms in the regulation of galacturonic acid-induced genes in Aspergillus niger. Fungal Genet Biol 82:32-42

Oliveira DM, Finger-Teixeira A, Mota TR, Salvador VH, Moreira-Vilar FC, Molinari HB, Mitchell RA, Marchiosi R, Ferrarese-Filho O, dos Santos WD (2015) Ferulic acid: a key component in grass lignocellulose recalcitrance to hydrolysis. Plant Biotechnol J 13(9):1224-1232. https:// doi.org/10.1016/j.ophtha.2013.03.046

Oliveira DM, Mota TR, Oliva B, Segato F, Marchiosi R, Ferrarese-Filho O, Faulds CB, dos Santos WD (2019) Feruloyl esterases: biocatalysts to overcome biomass recalcitrance and for the production of bioactive compounds. Bioresour Technol 278:408-423. https://doi.org/10.1016/j.ophtha. 2013.03.046

Pel HJ, de Winde JH, Archer DB, Dyer PS, Hofmann G, Schaap PJ, Turner G, de Vries RP, Albang R, Albermann K, Andersen MR, Bendtsen JD, Benen JA, van den Berg M, Breestraat S, Caddick MX, Contreras R, Cornell M, Coutinho PM, Danchin EG, Debets AJ, Dekker P, van Dijck PW, van Dijk A, Dijkhuizen L, Driessen AJ, d'Enfert C, Geysens S, Goosen C, Groot GS, de Groot PW, Guillemette T, Henrissat B, Herweijer M, van den Hombergh JP, van den Hondel CA, van der Heijden RT, van der Kaaij RM, Klis FM, Kools HJ, Kubicek CP, van Kuyk PA, Lauber J, Lu X, van der Maarel MJ, Meulenberg R, Menke H, Mortimer MA, Nielsen J, Oliver SG, Olsthoorn M, Pal K, van Peij NN, Ram AF, Rinas U, Roubos JA, Sagt CM, Schmoll M, Sun J, Ussery D, Varga J, Vervecken W, van de Vondervoort PJ, Wedler H, Wösten HA, Zeng AP, van Ooyen AJ, Visser J, Stam H (2007) Genome sequencing and analysis of the versatile cell factory Aspergillus niger CBS 513.88. Nat Biotechnol 25:221-231

Poovaiah CR, Nageswara-Rao M, Soneji JR, Baxter HL, Stewart CN Jr (2014) Altered lignin biosynthesis using biotechnology to improve lignocellulosic biofuel feedstocks. Plant Biotechnol J 12(9):1163-1173. https://doi. org/10.1016/j.ophtha.2013.03.046

Punt PJ, van den Hondel CA (1992) Transformation of filamentous fungi based on hygromycin $\mathrm{B}$ and phleomycin resistance markers. Methods Enzymol 216:447-457

Punt PJ, Oliver RP, Dingemanse MA, Pouwels PH, van den Hondel CA (1987) Transformation of Aspergillus based on the hygromycin B resistance marker from Escherichia coli. Gene 56(1):117-124

Reijngoud J, Deseke M, Halbesma ETM, Alazi E, Arentshorst M, Punt PJ, Ram AF (2019) Mutations in AraR leading to constitutive expression of arabinolytic genes in Aspergillus niger under derepressing conditions. Appl Microbiol Biotechnol 103(10):4125-4136. https://doi.org/10.1007/ s00253-019-09777-0

Ries LN, Beattie SR, Espeso EA, Cramer RA, Goldman GH (2016) Diverse regulation of the CreA carbon catabolite repressor in Aspergillus nidulans. Genetics 203(1):335-352. https://doi.org/10.1534/genetics.116. 187872

Ruijter GJ, Visser J (1997) Carbon repression in Aspergilli. FEMS Microbiol Lett 15(2):103-114 151(

Selig MJ, Knoshaug EP, Adney WS, Himmel ME, Decker SR (2008) Synergistic enhancement of cellobiohydrolase performance on pretreated corn stover by addition of xylanase and esterase activities. Bioresour Technol 99(11):4997-5005

Tabka MG, Herpoël-Gimbert I, Monod F, Asther M, Sigoillot JC (2006) Enzymatic saccharification of wheat straw for bioethanol production by a combined cellulase xylanase and feruloyl esterase treatment. Enzyme Microbial Technol 39(4):897-902. https://doi.org/10.1016/j.enzmictec. 2006.01.021

Terrett OM, Dupree P (2019) Covalent interactions between lignin and hemicelluloses in plant secondary cell walls. Curr Opin Biotechnol 56:97-104. https://doi.org/10.1016/ j.ophtha.2013.03.046

van Hartingsveldt W, Mattern IE, van Zeijl CM, Pouwels PH, van den Hondel CA (1987) Development of a homologous transformation system for Aspergillus niger based on the pyrG gene. Mol Gen Genet 206(1):71-75

van Peij NN, Gielkens MM, de Vries RP, Visser J, de Graaff LH (1998) The transcriptional activator XlnR regulates both xylanolytic and endoglucanase gene expression in Aspergillus niger. Appl Environ Microbiol 64(10):3615-3619

Wong DW, Chan VJ, Liao H, Zidwick MJ (2013) Cloning of a novel feruloyl esterase gene from rumen microbial metagenome and enzyme characterization in synergism with endoxylanases. $\mathrm{J}$ Ind Microbiol Biotechnol 40(3-4):287-295. https://doi.org/10.1007/s10295-0131234-1

Publisher's note Springer Nature remains neutral with regard to jurisdictional claims in published maps and institutional affiliations. 